\title{
PERKEMBANGAN EMBRIO DAN PENETASAN TELUR IKAN KERAPU LUMPUR (Epinephelus coioides) DENGAN SUHU INKUBASI BERBEDA
}

\author{
Regina Melianawati, Philip Teguh Imanto, Made Suastika, dan Agus Prijono
}

\begin{abstract}
ABSTRAK
Untuk menopang keberhasilan usaha budi daya ikan kerapu lumpur maka penelitian mengenai perkembangan embrio telur dan suhu inkubasi merupakan informasi dasar yang penting untuk diketahui. Penelitian ini bertujuan untuk mengetahui pola perkembangan embrio, masa inkubasi dan derajat tetas telur ikan kerapu lumpur pada beberapa tingkat suhu inkubasi serta ukuran panjang total, volume kuning telur, dan butir minyak larva hasil tetasannya. Suhu inkubasi yang diuji adalah (A) $21-22^{\circ} \mathrm{C}$, (B) $24-25^{\circ} \mathrm{C}$, (C) $27-28^{\circ} \mathrm{C}$, dan (D) $30-31^{\circ} \mathrm{C}$. Penelitian dilakukan menggunakan becker glass volume $1 \mathrm{~L}$ yang ditempatkan dalam waterbath. Hasil penelitian menunjukkan bahwa telur yang diinkubasikan pada suhu $24-31^{\circ} \mathrm{C}$ menghasilkan pola perkembangan embrio yang teratur, sedangkan pada suhu $21-22^{\circ} \mathrm{C}$ telur berkembang tidak normal sehingga tidak menetas. Masa inkubasi pada perlakuan (B), (C), dan (D) adalah 24 jam 30 menit, 17 jam 30 menit, dan 14 jam 30 menit dengan masing-masing derajat tetas sebesar $36 \%, 50 \%$, dan $82 \%$. Ukuran panjang total larva yang menetas dari masing-masing perlakuan tersebut adalah 1,62 mm; 1,68 mm; dan 1,77 mm dengan ukuran volume kuning telur 0,15369 $\mathrm{mm}^{3} ; 0,13095 \mathrm{~mm}^{3}$; dan $0,13641 \mathrm{~mm}^{3}$; sedangkan volume butir minyaknya sama yaitu sebesar $0,00419 \mathrm{~mm}^{3}$.
\end{abstract}

ABSTRACT: Embryonic development and hatching of orangespotted grouper(Epinephelus coioides) egg under different incubation temperatures. By: Regina Melianawati, Philip Teguh Imanto, Made Suastika, and Agus Prijono

For supporting the success of orange spotted grouper culture, a research on embryonic development and incubation temperature will be animportant basic information. This research aimed to gain information on the embryonic development pattern, incubation temperature and hatching rate of orange spotted grouper egg under different incubation temperatures, as well as hatched larvae total length and volumes of yolk and oil globules of each incubation treatment. Four treatments were $(A) 21-22^{\circ} \mathrm{C},(B) 24-25^{\circ} \mathrm{C},(C) 27-28^{\circ} \mathrm{C}$, and $(D) 30-31^{\circ} \mathrm{C}$. The result showed that eggs incubated under temperature range of $24-31^{\circ} \mathrm{C}$ had normal sequence of embryonic development pattern. Where as under temperature $21-22^{\circ} \mathrm{C}$, they performed irregular sequence and the egg could not successfully hatched. Incubation periods on treatment (B), (C), and (D) were 24 hours 30 minute, 17 hours 30 minute, and 14 hours 30 minute, with in hatching rates of $36 \%, 50 \%$, and $82 \%$, respectively. Total lengths of larvae in each treatment were $1.62 \mathrm{~mm}, 1.68 \mathrm{~mm}$, and 1.77 $\mathrm{mm}$ with volumes of yolk of $0.15369 \mathrm{~mm}^{3}, 0.13095 \mathrm{~mm}^{3}$, and $0.13641 \mathrm{~mm}^{3}$ respectively. Volumes of oil globules of each treatment were the same, reaching $0.00419 \mathrm{~mm}^{3}$.

\section{KEYWORDS: $\quad$ orange spotted grouper, temperature, embryo}

\section{PENDAHULUAN}

Ikan kerapu merupakan salah satu komoditas ikan laut yang mempunyai nilai ekonomis tinggi. Usaha budi daya ikan kerapu di Indonesia pertama kali dirintis pada tahun 1978 oleh para nelayan di Kepulauan Riau dengan menggunakan sistem kurungan tancap. Usaha ini kemudian berkembang ke Pulau Bengkalis, Sulawesi Selatan, Kepulauan Seribu, Karimunjawa, Teluk Banten, dan lain-lain (Mansyur et al., 1995). Hingga saat ini usaha budi daya beberapa jenis ikan kerapu yang telah dilakukan di Indonesia di antaranya adalah kerapu macan,
Epinephelus fuscoguttatus (Kohno et al., 1990); kerapu sunu, Plectropomus maculatus (Diani et al., 1991); kerapu bebek, Cromileptes altivelis (Tridjoko et al., 1999); dan kerapu batik, E. microdon (Slamet \& Tridjoko, 1997)

Ikan kerapu lumpur (Epinephelus coioides) merupakan satu di antara jenis-jenis ikan kerapu yang bernilai ekonomis tinggi dan banyak dipasarkan dalam keadaan hidup untuk konsumsi, baik di dalam maupun di luar negeri (Lau \& Jones, 1999). Sumber benih ikan kerapu ini tersebar di seluruh perairan Indonesia dan banyak ditangkap dengan menggunakan bubu, jaring pantai, dan pancing (Sunyoto \& Muslikh, 1991).

\footnotetext{
-) Peneliti pada Balai Besar Riset Perikanan Budidaya Laut, Gondol
} 
Mengingat tingginya permintaan pasar dan tingkat pengusahaan terhadap jenis ikan kerapu ini, maka usaha budi dayanya mutlak segera dilakukan untuk mencegah terjadinya kepunahan di alam. Beberapa sifat ikan kerapu lumpur yang menguntungkan untuk usaha budi daya adalah pertumbuhannya yang relatif cepat serta toleran terhadap kekeruhan, ruang yang terbatas, dan salinitas (Purba \& Basyarie, 1992).

Hingga saat ini penelitian ikan kerapu lumpur lebih banyak dilakukan pada usaha pembesaran dengan menggunakan benih yang berasal dari tangkapan di alam (Mayunar, 1991; Basyarie \& Putra, 1991). Penelitian mengenai perkembangan embrio telur dan suhu inkubasi merupakan informasi dasar yang penting untuk diketahui dalam menopang keberhasilan usaha perbenihan ikan kerapu lumpur. Penelitian ini bertujuan untuk mengetahui pola perkembangan embrio, masa inkubasi, dan derajat tetas telur ikan kerapu lumpur pada beberapa tingkat suhu inkubasi serta ukuran panjang total, kuning telur, dan butir minyak larva hasil tetasan pada masing-masing suhu inkubasi tersebut.

\section{BAHAN DAN METODE}

Penelitian dilakukan di Laboratorium Balai Besar Riset Perikanan Budidaya Laut Gondol-Bali. Telur yang digunakan dalam penelitian ini merupakan hasil pemijahan secara alami induk kerapu lumpur yang dipelihara pada tangki beton volume 100 ton. Pemijahan terjadi pada malam hari antara pukul 22.00 - 02.00 WITA. Sesaat setelah pemijahan telur terkumpul di dalam kantong penampungan telur yang terbuat dari bahan nylon monofilament dengan ukuran mata jaring 300-400 micron. Kantong penampungan telur ini berukuran $1 \times 1 \mathrm{~m}^{2}$ dan ditempatkan pada bak telur yang berada di sisi luar bak induk. Telur yang terkumpul kemudian diambil dengan serok telur dan dipindahkan ke dalam bak fiberglass volume $30 \mathrm{~L}$ tanpa diberi aerasi, selanjutnya diseleksi antara telur yang dibuahi (fertil) dan yang tidak dibuahi (infertil). Dalam proses seleksi ini telur-telur yang dibuahi (transparan) akan berada di lapisan atas (mengapung) sedangkan telur yang tidak dibuahi (berwarna putih keruh) akan tenggelam. Selanjutnya hanya telur yang dibuahi saja yang digunakan untuk pengamatan.

Perlakuan suhu inkubasi yang diujikan dalam penelitian ini adalah (A) $21-22^{\circ} \mathrm{C},(\mathrm{B}) 24-25^{\circ} \mathrm{C}$, (C) 27 $28^{\circ} \mathrm{C}$, dan (D) $30-31^{\circ} \mathrm{C}$. Masing-masing perlakuan terdiri atas 3 ulangan. Saat awal penempatan telur, media inkubasi berada dalam kondisi suhu ruang, selanjutnya pengaturan suhu inkubasi dilakukan pada saat telur telah berada pada stadia 2 (blastula). Pengaturan ini didasarkan pada hasil pengamatan terdahulu, di mana inkubasi telur dengan suhu rendah pada awal pembelahan sel (stadia 1) mengakibatkan perkembangan embrio terhenti setelah stadia 3 (gastrula).

Wadah yang digunakan dalam penelitian ini adalah gelas becker volume $1 \mathrm{~L}$ sebanyak 12 buah. Ke dalam masing-masing gelas becker diisi air laut steril sebanyak $1 \mathrm{~L}$ dan diinkubasikan telur ikan kerapu lumpur sebanyak 250 butir. Setiap 3 buah becker glass tersebut ditempatkan dalam sebuah wadah plastik berbentuk empat persegi panjang dengan volume 46 $\mathrm{L}$ yang diisi air sebanyak $12 \mathrm{~L}$. Setiap wadah plastik inkubasi merupakan perlakuan dengan ulang-annya. Selanjutnya masing-masing wadah inkubasi ditempatkan dalam sebuah waterbath yang telah dilengkapi dengan alat pengatur suhu. Suhu pada waterbath diatur pada $20^{\circ} \mathrm{C}-21^{\circ} \mathrm{C}$ untuk menyesuaikan dengan suhu terendah yang diujikan dalam penelitian ini. Untuk meningkatkan suhu pada tempat inkubasi yang lain digunakan pemanas berbentuk batang dan berkekuatan 125 watt. Skema peralatan selengkapnya dapat dilihat pada Gambar 1.

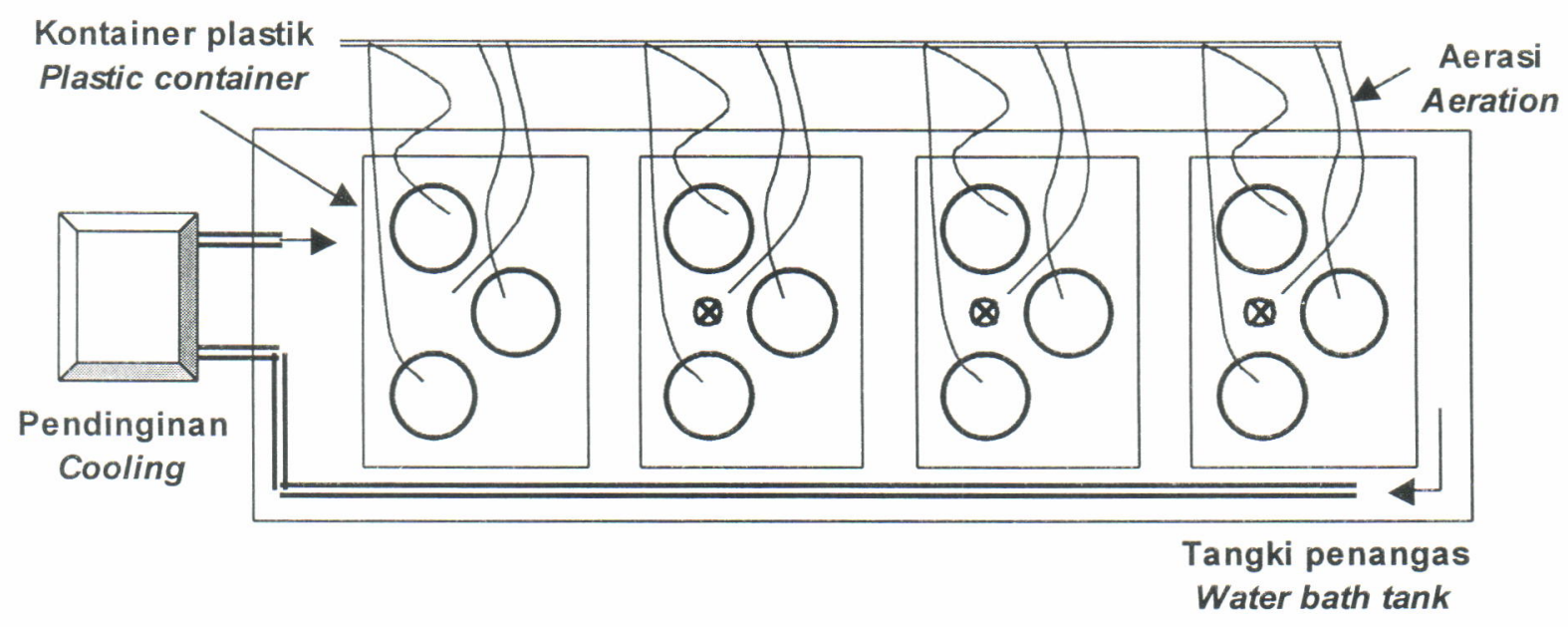

Gambar 1. Skema peralatan untuk pengamatan inkubasi telur ikan kerapu lumpur Figure 1. Schematic diagram of incubation observation apparatus (water bath system) 
Pengamatan perkembangan embrio dilakukan dengan cara mengambil 10 butir sampel telur secara acak dari ketiga gelas becker pada masing-masing perlakuan dengan menggunakan pipet dan menempatkannya pada single concave object glass. Perkembangan embrio diamati pada saat telur diinkubasikan sampai dengan telur menetas. Interval waktu pengambilan sampel telur adalah setiap 1 jam. Masa inkubasi telur dihitung mulai dari waktu pemijahan (Time After Spawning) sampai dengan menetasnya seluruh telur yang diamati.

Untuk memudahkan pengamatan perkembangan embrio, dibuat klasifikasi perkembangan dalam 7 stadia yang diperinci sebagai berikut: stadia 1 dimulai dari pembuahan sampai dengan multisel; stadia 2 blastula; stadia 3 gastrula; stadia 4 pembentukan bayangan embrio dan rongga mata; stadia 5 ditandai dengan pembentukan kuppfer vesicle dan lensa mata; stadia 6 jantung mulai berdetak, ekor meruncing, dan terlihat sudah ada pergerakan embrio; dan stadia 7 embrio menetas (Gambar 2).

Larva yang menetas dari masing-masing perlakuan diambil sebanyak 5 ekor dan diamati panjang total menggunakan rumus: $V=4 / 3 \cdot \pi r^{3}$ di mana $r$ adalah jari-jari butir minyak (Blaxter \& Hempel, 1963 dalam Kohno et al., 1986). Analisis regresi dilakukan dengan menggunakan data rata-rata dari setiap perlakuan.

\section{HASIL DAN BAHASAN}

Hasil pengamatan terhadap perkembangan embrio telur ikan kerapu lumpur dapat dilihat pada Tabel 1, di mana perkembangan embrio telur ikan kerapu lumpur pada saat perlakuan umumnya berada pada perkembangan stadia 2 dengan jumlah lebih dari stadia $80 \%$ dan stadia 3 kurang dari $20 \%$. Selanjutnya perkembangan embrio stadia 4 mulai terjadi setelah 9 jam 30 menit pada suhu inkubasi $21-22^{\circ} \mathrm{C}$ (A) 4 jam 30 menit pada suhu inkubasi $24-25^{\circ} \mathrm{C}(\mathrm{B})$, sedangkan dengan suhu inkubasi $27^{\circ} \mathrm{C}-28^{\circ} \mathrm{C}(\mathrm{C})$, dan $30^{\circ} \mathrm{C}-31^{\circ} \mathrm{C}$ (D) terjadi pada waktu yang sama yaitu setelah 3 jam 30 menit masa inkubasi

Perkembangan embrio stadia 5 terjadi setelah 11 jam 30 menit masa inkubasi pada perlakuan (A), sedangkan pada perlakuan (B), (C), dan (D) masingmasing setelah 9 jam 30 menit, 8 jam 30 menit, dan 4 jam 30 menit. Perkembangan embrio stadia 6 terjadi

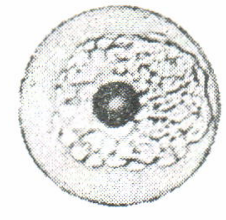

A

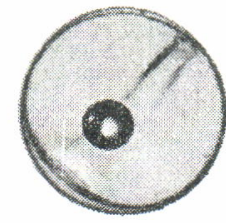

D

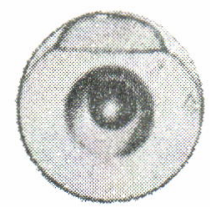

B

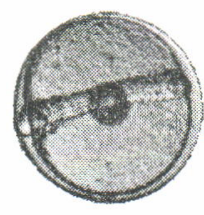

E

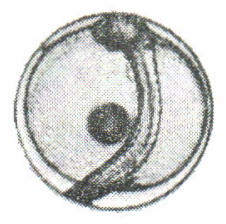

$\mathbf{F}$

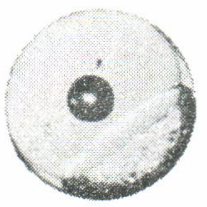

C

Gambar 2. Pengelompokan stadia perkembangan embrio telur ikan kerapu lumpur A. Multisel; B. Blastula; C. Gastrula; D. Bayangan embrio; E. Embrio dengan kuppfer vesicle; F. Embrio bergerak; G. Menetas

Figure 2. Grouping of embryonic development stage of orangespotted grouper egg A. Multicell; B. Blastula; C. Gastrula; D. Embryonic shield; E. Embryo with kuppfer vesicle; F. Movement of embryo; G. Hatching

serta volume kuning telur dan butir minyaknya. Sampel larva diambil dengan menggunakan pipet lalu diletakkan pada gelas objek dan selanjutnya dilakukan pengukuran dengan bantuan stereoskopis mikroskop Olympus yang telah dilengkapi dengan mikrometer. Parameter yang diamati meliputi panjang total, volume kuning telur, dan butir minyak. Volume kuning telur dihitung dengan rumus: $\mathrm{V}=\pi / 6 . \mathrm{Ih}^{2}$ di mana I adalah panjang kuning telur dan $\mathrm{h}$ adalah tinggi kuning telur, sedangkan volume butir minyak dihitung dengan setelah 23 jam 30 menit, 17 jam 30 menit, 12 jam 30 menit, dan 11 jam 30 menit pada perlakuan (A), (B), (C), dan (D). Untuk perkembangan embrio stadia 7 hanya terjadi pada perlakuan $(B),(C)$, dan $(D)$ yaitu pada 24 jam 30 menit, 17 jam 30 menit, dan 15 jam 30 menit masa inkubasi. Pada perlakuan (A), stadia 7 tidak dapat dicapai karena perkembangan embrio terhenti.

Secara keseluruhan terlihat bahwa pada media inkubasi dengan suhu rendah, proses perkembangan 
embrio setiap stadia terjadi lebih lambat dibandingkan dengan media inkubasi pada suhu tinggi. Dengan

Perkembangan embrio telur ikan kerapu lumpur demikian telah diketahui bahwa suhu pada media yang diinkubasikan pada media dengan suhu berkisar antara $24^{\circ} \mathrm{C}-31^{\circ} \mathrm{C}$ (perlakuan $\mathrm{B}, \mathrm{C}$, dan $\mathrm{D}$ ) cenderung

Tabel 1. Tahapan waktu perkembangan embrio telur ikan kerapu lumpur yang diinkubasikan pada suhu berbeda (jam:menit)

Table 1. Embryonic development time of orange spotted grouper incubated under different temperature (hour:minute)

\begin{tabular}{ccccccc}
\hline \multirow{2}{*}{$\begin{array}{c}\text { Perlakuan } \\
\text { Treatment }\end{array}$} & \multicolumn{6}{c}{ Stadia embrio (Embryonic stage) (TAS) } \\
\cline { 2 - 7 } & $\mathbf{2}$ & $\mathbf{3}$ & $\mathbf{4}$ & $\mathbf{5}$ & $\mathbf{6}$ & $\mathbf{7}$ \\
\hline A & $2: 30$ & $2: 30$ & $9: 30$ & $11: 30$ & $23: 30$ & - \\
B & $2: 30$ & $2: 30$ & $4: 30$ & $9: 30$ & $17: 30$ & $24: 30$ \\
C & $2: 30$ & $2: 30$ & $3: 30$ & $8: 30$ & $12: 30$ & $17: 30$ \\
D & $2: 30$ & $2: 30$ & $3: 30$ & $4: 30$ & $11: 30$ & $14: 30$ \\
\hline
\end{tabular}

inkubasi berpengaruh terhadap proses dan kecepatan perkembangan embrio ikan kerapu lumpur. Sedangkan pola perkembangan masing-masing stadia pada embrio telur ikan kerapu lumpur yang diinkubasikan pada media dengan suhu berbeda dapat dilihat pada Gambar 3. membentuk pola yang hampir sama. Dari ketujuh tahapan stadia perkembangan yang diamati, stadia 5 cenderung berlangsung paling lama. Perbedaan yang terlihat pada setiap perlakuan adalah kecepatan perkembangan pada masing-masing stadia. Pada media inkubasi dengan suhu yang lebih tinggi nampak
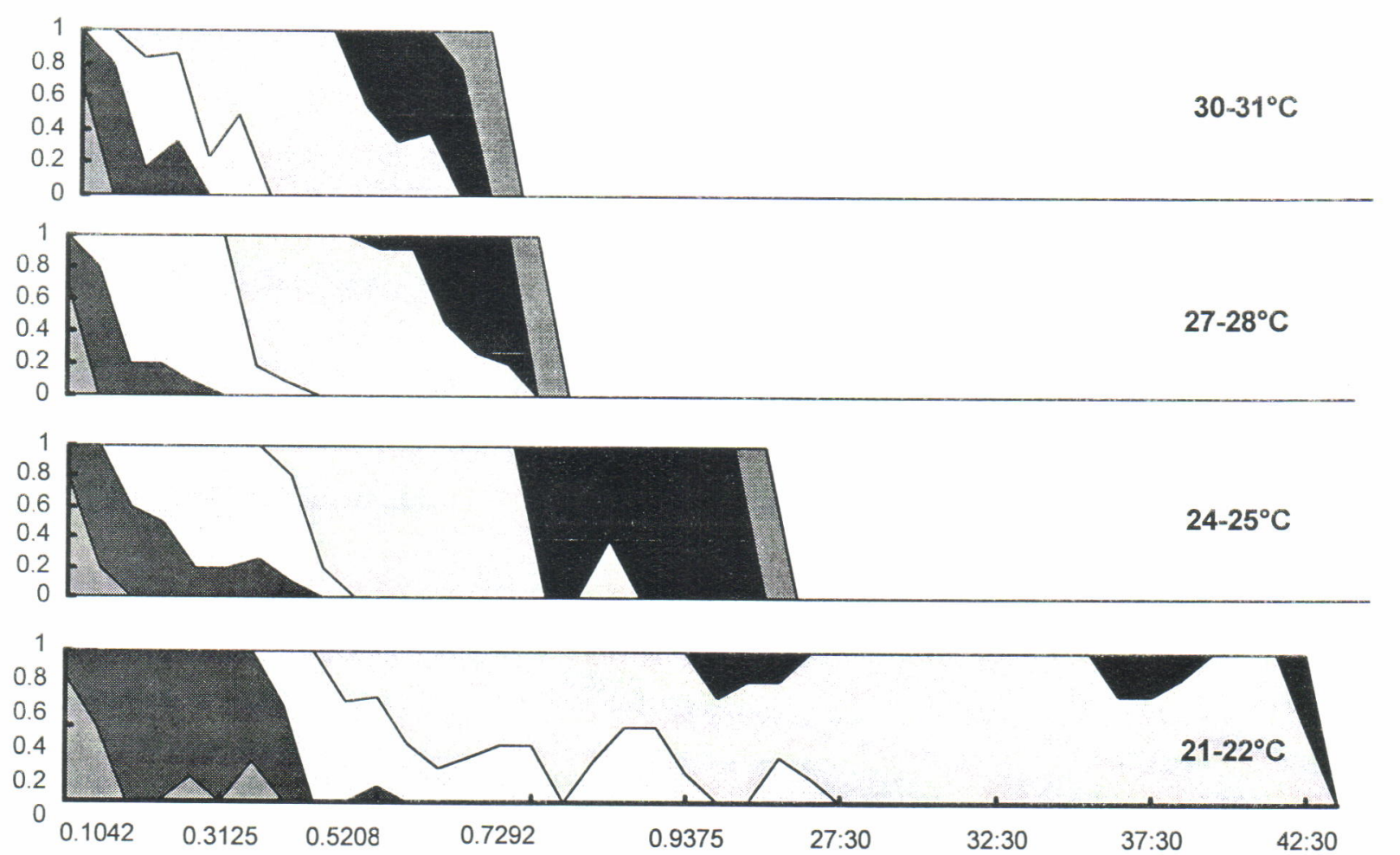

Waktu /Hari (Time /Hour)

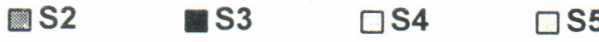
인 57

Gambar 3. Pola perkembangan embrio telur ikan kerapu lumpur yang diinkubasi pada suhu berbeda $(\mathrm{S}=$ stadia)

Figure 3. Embryonic development pattern of orangespotted grouper incubated under deifferent temperature ( $S$ = stage) 
bahwa perkembangan embrio pada setiap stadia terjadi lebih cepat dibandingkan pada media inkubasi dengan suhu yang lebih rendah.

Pada inkubasi dengan suhu terendah (perlakuan A) pola perkembangan embrionya berbeda dengan perlakuan lainnya yaitu adanya ketidakteraturan pola perkembangan embrio mulai dari awal hingga akhir masa inkubasi. Kondisi suhu media yang rendah diduga berpengaruh terhadap ketidakteraturan tersebut sehingga menghambat proses perkembangan embrio
Perkembangan stadia pada perlakuan (B) relatif lambat sehingga masa inkubasi berlangsung selama 24 jam 30 menit, sedangkan pada perlakuan (C) dan (D) terjadi lebih cepat yaitu 17 jam 30 menit dan 14 jam 30 menit (Tabel 2).

Secara alami masa inkubasi telur ikan kerapu lumpur tergantung pada suhu media, seperti halnya yang dilaporkan oleh Cheong \& Chuan (1980) bahwa di Singapura masa inkubasi telur ikan kerapu lumpur (E. tauvina) berlangsung selama 23-25 jam pada suhu

Tabel 2. Pengaruh suhu inkubasi pada masa inkubasi dan derajat penetasan telur serta penampilan fisik larva ikan kerapu lumpur setelah menetas

Table 2. Impact of temperature media for incubation period and the hatching rate and the physical performance of newly hatched orange spotted grouper larvae

\begin{tabular}{|c|c|c|c|c|}
\hline \multirow{2}{*}{$\begin{array}{l}\text { Parameter } \\
\text { Parameter }\end{array}$} & \multicolumn{4}{|c|}{ Perlakuan (Treatment) } \\
\hline & A & B & C & D \\
\hline \multicolumn{5}{|l|}{ Telur (Egg) } \\
\hline $\begin{array}{l}\text { Masa inkubasi (jam:menit) } \\
\text { Incubation period (hour:menit) }\end{array}$ & - & $24: 30$ & $17: 30$ & $14: 30$ \\
\hline $\begin{array}{l}\text { Derajat tetas }(\%) \\
\text { Hatching rate }(\%)\end{array}$ & 0.0 & 35.6 & 49.6 & 81.8 \\
\hline \multicolumn{5}{|l|}{ Larva (Larvae) } \\
\hline $\begin{array}{l}\text { Panjang total }(\mathrm{mm}) \\
\text { Total length }(\mathrm{mm})\end{array}$ & - & $1.62 \pm 0.148$ & $1.68 \pm 0.192$ & $1.77 \pm 0.109$ \\
\hline $\begin{array}{l}\text { Volume kuning telur }\left(\mathrm{mm}^{3}\right) \\
\text { Volume of yolk }\left(\mathrm{mm}^{3}\right)\end{array}$ & - & $0.15369 \pm 0.041$ & $0.13095 \pm 0.038$ & $0.13641 \pm 0.019$ \\
\hline $\begin{array}{l}\text { Volume butir minyak }\left(\mathrm{mm}^{3}\right) \\
\text { Oil globule }\left(\mathrm{mm}^{3}\right)\end{array}$ & - & $0.00419 \pm 0.000$ & $0.00419 \pm 0.000$ & $0.00419 \pm 0.000$ \\
\hline
\end{tabular}

telur ikan kerapu lumpur. Dari hasil tersebut dapat diketahui bahwa telur ikan kerapu lumpur tidak dapat diinkubasikan pada media dengan suhu $21^{\circ} \mathrm{C}-22^{\circ} \mathrm{C}$.

Hasil penelitian pendahuluan menunjukkan bahwa pemberian suhu rendah pada awal pembuahan mengakibatkan perkembangan telur terhenti sampai stadia 3. Namun jika inkubasi mulai dilakukan dari stadia 2 , proses perkembangan embrio dapat berlangsung hingga stadia akhir, namun telur tidak berhasil menetas. Dengan demikian batas suhu terendah yang dapat digunakan untuk inkubasi telur ikan kerapu lumpur adalah $24^{\circ} \mathrm{C}-25^{\circ} \mathrm{C}$. Perkembangan embrio pada suhu rendah hampir sama seperti yang terjadi pada inkubasi telur ikan kerapu batik dan kerapu macan yang mengakibatkan perkembangan telur terhenti, masing-masing pada fase gastrula (Melianawati et al., 2001) dan tingkat pertengahan embrio (Slamet, 1993).

Kecepatan perubahan stadia pada perkembangan embrio berpengaruh terhadap lamanya masa inkubasi. $27^{\circ} \mathrm{C}-28^{\circ} \mathrm{C}$ dan selama $20-22$ jam pada suhu $29^{\circ} \mathrm{C}$ $30^{\circ} \mathrm{C}$. Sedangkan Chen et al. (1977) mengemukakan bahwa penetasan telur dari jenis ikan yang sama terjadi setelah 23-25 jam masa inkubasi pada suhu $27^{\circ} \mathrm{C}$. Dari Kuwait dilaporkan pula bahwa penetasan telur jenis ikan tersebut terjadi setelah 26-35 jam inkubasi pada kondisi suhu $27^{\circ} \mathrm{C}-30^{\circ} \mathrm{C}$ (Hussain et al., 1975).

Hubungan antara suhu pada media inkubasi dengan masa inkubasi dapat dilihat pada Gambar 4 dengan persamaan: $y=73.39 x^{-0.3515}$ di mana dapat diketahui adanya hubungan yang erat antara suhu media inkubasi dengan waktu inkubasi. Nampak adanya kecenderungan bahwa penurunan suhu akan dapat memperpanjang masa inkubasi telur dan waktu terjadinya penetasan.

Derajat tetas telur dari perlakuan $(A),(B),(C)$, dan (D) masing-masing adalah $0 \%, 36 \%, 50 \%$, dan $82 \%$. Derajat tetas telur ikan kerapu lumpur yang baik adalah pada inkubasi dengan suhu berkisar antara $27^{\circ} \mathrm{C}-31^{\circ} \mathrm{C}$. Rendahnya derajat tetas pada perlakuan (B) 


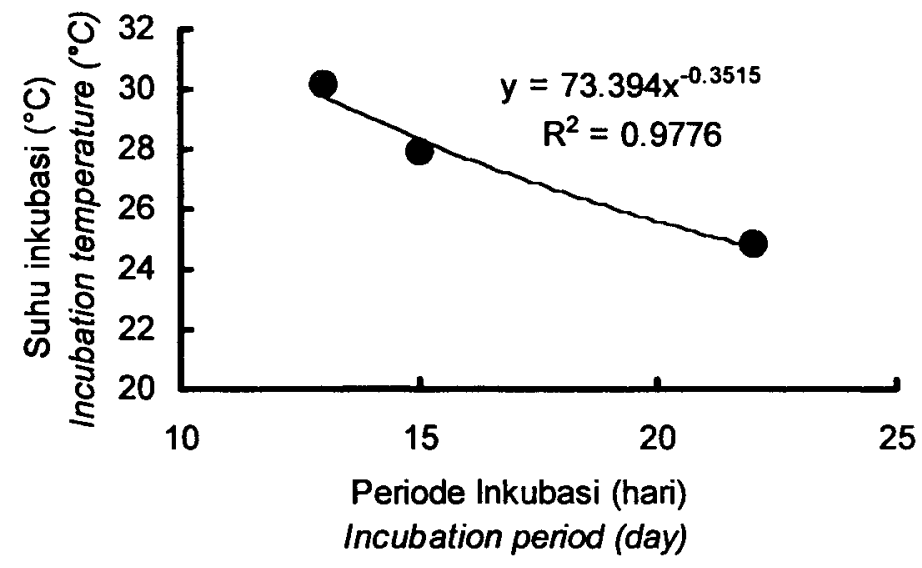

Gambar 4. Hubungan antara suhu inkubasi dengan masa inkubasi telur ikan kerapu lumpur

Figure 4. Relationship between incubation temperature and incubation time of orangespotted grouper egg

diakibatkan oleh banyaknya proses perkembangan embrio yang terhenti pada stadia 5 dan 6 .

Rata-rata ukuran panjang total larva yang baru menetas dari perlakuan (B), (C), dan (D) masingmasing adalah $1,62 \mathrm{~mm} ; 1,68 \mathrm{~mm}$; dan $1,77 \mathrm{~mm}$. Dari hasil tersebut nampak bahwa larva yang menetas dari media inkubasi dengan suhu yang tinggi cenderung berukuran lebih panjang, sedangkan dengan suhu inkubasi rendah panjang larva yang dihasilkan berukuran relatif lebih pendek. Dalam hal ini terlihat bahwa suhu pada media inkubasi berperanan terhadap kece-patan proses metabolisme telur selama dalam proses perkembangannya. Hasil analisis regresi antara masa inkubasi dengan panjang total larva yang dihasilkan menunjukkan adanya hubungan yang positif (Gambar 5). butir minyak dari ketiga perlakuan tersebut adalah sama yaitu $0,00419 \mathrm{~mm}^{3}$. Hal ini membuktikan bahwa kecepatan menetas larva karena pengaruh suhu tinggi tidak berpengaruh nyata pada volume kuning telur (Gambar 6) dan butir minyak.

\section{KESIMPULAN}

* Suhu media inkubasi berpengaruh terhadap pola perkembangan embrio, masa inkubasi, derajat tetas telur ikan kerapu lumpur, ukuran panjang total dan volume kuning telur larva yang menetas.

* Terdapat suatu hubungan yang positif antara suhu pada media inkubasi dengan panjang total larva.

* Terdapat hubungan yang negatif antara suhu pada media inkubasi dengan lama masa inkubasi telur dan volume kuning telur larva.

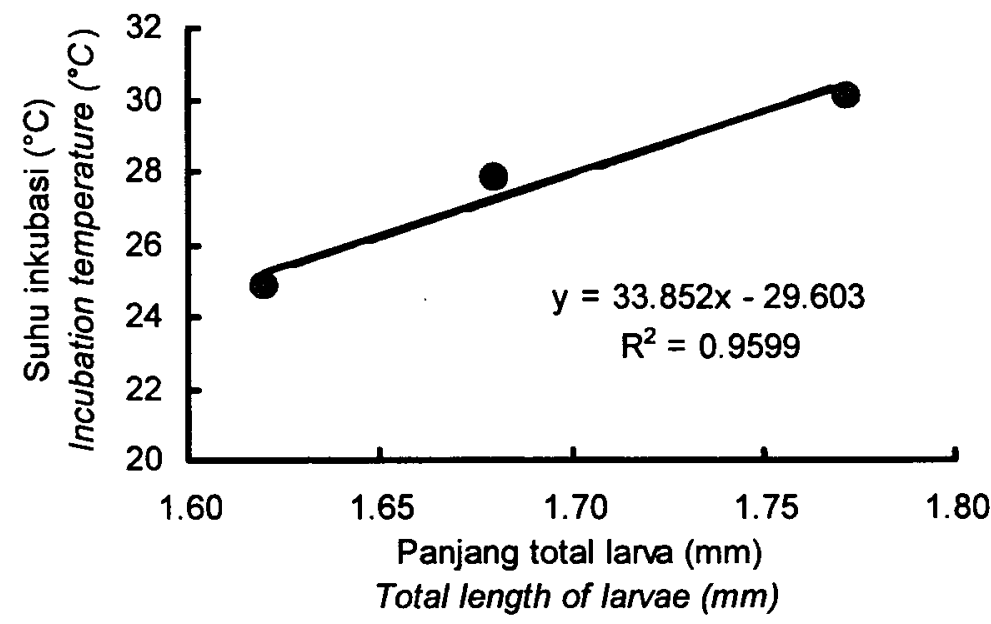

Gambar 5. Hubungan antara suhu media inkubasi dengan panjang total larva

Figure 5. Relationship between incubation temperature and total length of orangespotted grouper larvae

Volume kuning telur larva yang menetas pada perlakuan (B), (C), dan (D) adalah $0,15369 \mathrm{~mm}^{3}$; $0,13095 \mathrm{~mm}^{3}$; dan $0,13641 \mathrm{~mm}^{3}$, sedangkan volume
* Suhu media yang dapat digunakan untuk inkubasi telur ikan kerapu lumpur berkisar antara $24^{\circ} \mathrm{C}$ hingga $31^{\circ} \mathrm{C}$. 


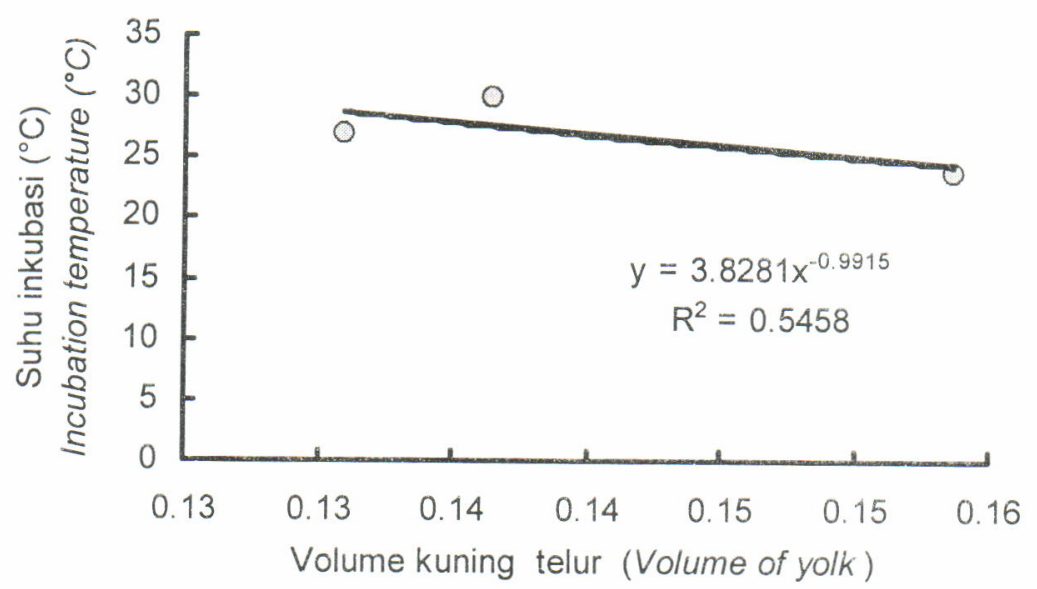

Gambar 6. Hubungan antara masa inkubasi dengan volume yolk larva

Figure 6. Relationship between incubation time with yolk volume of orangespotted grouper larvae

\section{DAFTAR PUSTAKA}

Basyarie, A. dan D.N. Putra. 1991. Pengaruh perbedaan sumber protein utama dalam makanan buatan terhadap pertumbuhan benih ikan kerapu lumpur Epinephelus tauvina. J. Penelitian Budidaya Pantai. 7(2):102-109.

Chen, F.Y., M. Chow, T.M. Chao, and R. Lim, 1977. Artificial spawning and larval rearing of the grouper, Epinephelus tauvina (Forskal) in Singapore. Singapore J. Pri. Ind. 5(1):1-21.

Cheong, L. and L.L. Chuan. 1980. Current Work on the Induced Breeding of Grouper Epinephelus tauvina, $F$. in Singapore. 4 pp.

Diani, S., B. Slamet, dan P.T. Imanto. 1991. Studi pendahuluan pemijahan alami dan perkembangan awal larva ikan kerapu sunu, Plectropomus maculatus. J. Penelitian Budidaya Pantai, Terbitan Khusus. 7(2):10-19.

Hussain, N., M. Saif, and M. Ukawa. 1975. On the Culture of Epinephelus tauvina (Forskal). Kuwait Institute for Scientific Research. 14 pp.

Kohno, H., S. Hara, and Y. Taki. 1986. Early larval development of the seabass Lates calcarifer with emphasis on the transition of energy sources. Bull. of the Japanese Society of Scientific Fisheries. 52(10): 1.719-1.725.

Kohno, H., P.T. Imanto, S. Diani, B. Slamet, and P. Sunyoto. 1990. Reproductive performance and early life history of the grouper, Epinephelus fuscoguttatus. Bull. Penelitian Perikanan, Special Edition. 1: 27-35.

Lau, P.P.F. and R.P. Jones. 1999. The Hongkong Trade in Live Reef Fish for Food. TRAFFIC East Asia and World Wide Fund for Nature Hongkong. 64 pp.

Mansyur, A., Utojo, dan F. Rasjid. 1995. Pemeliharaan ikan kerapu lumpur (Epinephelus tauvina Forsk.) pada beberapa tingkat salinitas dalam kondisi laboratorium. J. Penelitian Perikanan Indonesia. 1(4): 100-105.

Mayunar. 1991. Studi pendahuluan pertumbuhan ikan kerapu lumpur Epinephelus suillus pada berbagai substrat. J. Penelitian Budidaya Pantai. 7(2): 110116.

Melianawati, R., P.T. Imanto, M. Suastika, dan S. Lante. 2001. Laju perkembangan embrio dan derajat tetas telur ikan kerapu batik (Epinephelus microdon) pada beberapa suhu media inkubasi. Dalam A. Sudradjat, E.S. Heruwati, A. Poernomo, A. Rukyani, J. Widodo, dan E. Danakusumah(Eds.) Prosiding Seminar Teknologi Budi Daya Laut dan Pengembangan Sea Farming di Indonesia. Puslitbang Eksplorasi Laut dan Perikanan. 489 pp.

Purba, P. dan A. Basyarie, 1992. Pengaruh padat penebaran terhadap kelangsungan hidup dan biomassa ikan kerapu lumpur, Epinephelus suillus di tambak. J. Penelitian Budidaya Pantai. 8(5): 51-55.

Slamet, B. 1993. Pengaruh penurunan suhu media terhadap penundaan penetasan dan peningkatan optimasi kepadatan pada transportasi telur ikan kerapu macan, Epinephelus fuscoguttatus. J. Penelitian Budidaya Pantai. 9(5): 30-36.

Slamet, B. dan Tridjoko. 1997. Pengamatan pemijahan alami, perkembangan embrio dan larva ikan kerapu batik, Epinephelus microdon dalam bak terkontrol. J. Penelitian Perikanan Indonesia. 3(4): 40-50.

Sunyoto, P. dan M. Muslikh. 1991. Pembesaran ikan kerapu lumpur, Epinephelus suillus di keramba jaring apung. J. Penelitian Budidaya Pantai. 7(2): 117-121.

Tridjoko, B. Slamet, T. Aslianti, Wardoyo, S. Ismi, J.H. Hutapea, K.M. Setiawati, I. Rusdi, D. Makatutu, A. Prijono, T. Setiadharma, M. Hirokazu, and K. Shigeru. 1999. Research and Development: The Seed Production Technique of Humpback Grouper, Cromileptes altivelis. JICA and Gondol Research Station for Coastal Fisheries. 55 pp. 
R. Melianawati, P.T. Imanto, M. Suastika, dan A. Prijono 